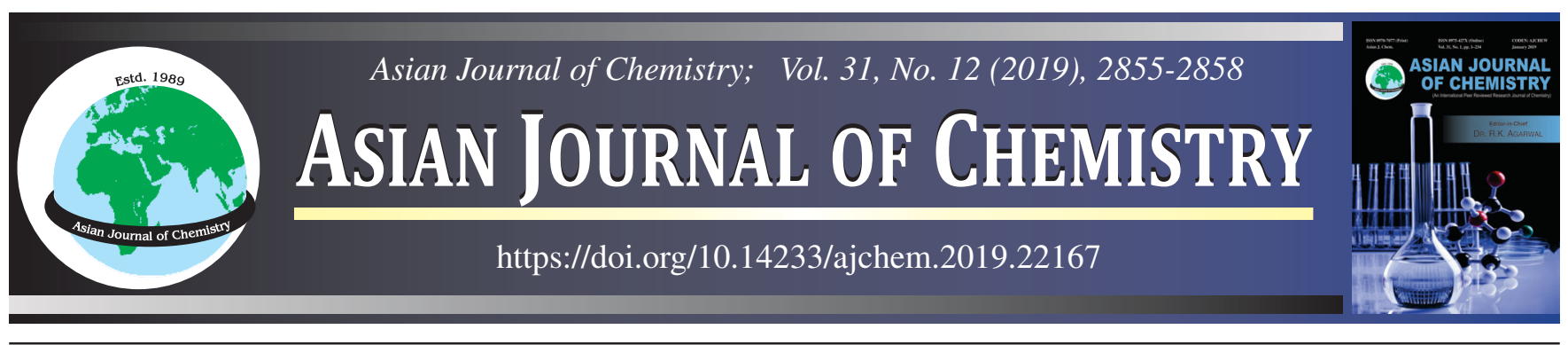

\title{
Physico-Chemical Profile of Essential oil of Kaffir Lime (Citrus hystrix DC) Grown in An Giang Province, Vietnam
}

\author{
Tran Thi Kim Ngan ${ }^{1,2,3}$, Tran Thien Hien ${ }^{1,2,3}$, Xuan Tien Le ${ }^{4, *}$, Trieu Tuan Anh ${ }^{5}$, Pham Minh Quan ${ }^{3,6}$, \\ Mai Huynh $\mathrm{Cang}^{7}$, Thuy Trang Le NGoc ${ }^{8}$, Vo Thanh Danh ${ }^{9}$, Le Nguyen Yen Trung and Tran Quoc Toan ${ }^{3,6}$
}

${ }^{1}$ Center of Excellence for Biochemistry and Natural Products, Nguyen Tat Thanh University, Ho Chi Minh City, Vietnam ${ }^{2}$ NTT Hi-Tech Institute, Nguyen Tat Thanh University, Ho Chi Minh City, Vietnam ${ }^{3}$ Institute of Natural Products Chemistry, Vietnam Academy of Science and Technology, Hanoi, Vietnam ${ }^{4}$ Department of Chemical Engineering, HCMC University of Technology, VNU-HCM, Ho Chi Minh City, Vietnam ${ }^{5}$ Faculty of Chemical Engineering and Food Technology, Nguyen Tat Thanh University, Ho Chi Minh City, Vietnam ${ }^{6}$ Graduate University of Science and Technology, Vietnam Academy of Science and Technology, Ha Noi, Viet Nam ${ }^{7}$ Chemical Engineering \& Processing Department, Nong Lam University, Ho Chi Minh city, Vietnam ${ }^{8}$ Institute of Applied Materials Science, Vietnam Academy of Science and Technology, 01 TL29, District 12, Ho Chi Minh City, Vietnam ${ }^{9}$ BKU Institute of Advanced Applied Science and Technology (BKIST), Ho Chi Minh City, Vietnam

*Corresponding author: E-mail: tien.le@hcmut.edu.vn

Received: 28 April 2019; Accepted: 28 July 2019; Published online: 16 November 2019; AJC-19631

In this study, kaffir lime peel was used for extraction of essential oil by hydrodistillation and evaluation of physico-chemical characteristics. The yield of essential oil was $1.8 \%$. The physico-chemical parameters averaged specific gravity $\left(0.8587 \mathrm{~g} / \mathrm{cm}^{3}\right)$, acid index $(0.667 \mathrm{mg}$ $\mathrm{KOH} / \mathrm{g}$ ), ester index $(4.203 \mathrm{mg} \mathrm{KOH} / \mathrm{g})$, refractive index (1.469), rotator power +3 . Twenty-three components were classified in kaffir lime peel oils. The result of GC-MS revealed that the oil is extremely rich in $\alpha$-pinene (35.54 \%), Eucalyptol (20.902 \%), camphene (4.384\%), bicyclo[3.1.1]hept-3-en-2-one (7.794\%), caryophyllene (1.225\%), endo-borneol (4.147 \%), bornyl acetate (4.065\%). The aim of this study is to promote for further research on extraction enhancement and application of that constituents to cosmetics, medicine and food industries to enhance antioxidant and anti-bacterial capabilities create more useful formulations.

Keywords: Essential oils, Kaffir lime, Citrus hystrix DC, GC-MS.

\section{INTRODUCTION}

In recent years, the use of plant in manufacturing of pharmaceutical products has become increasingly common. Different studies illustrated the activities and effectiveness of compounds derived from medicinal plants. Essential oils, obtained from different plant species have been used and in practical applications and in many fields of production such as antimicrobial compounds, medicine and food additives [1-10].

Kaffir lime (Citrus hystrix DC) belongs to the Rutaceae family which is cultivated mainly in different asian countries such as Vietnam and Thailand [11,12]. Kaffir lime has an excellent potential in scientific research due to the presence of a large number of bioactive compounds with antimicrobial and antioxidant activity. Previous study shows that there are different compounds obtained from essential oil kaffr lime peel such as $\alpha$-pinene, myrcene, terpinolene, and so on [13]. D-limonene is one of the significant constituents of kaffir lime, which prevents carcinogenic properties and is cancer chemopreventive [14]. Kaffir lime oil plays a vital role in the aromatherapy and cosmetic applications due to its antimicrobial activities [15]. Thirty-eight components were classified in the essential leaf oil of kaffir lime occupying $89 \%$ of the total oil [16].

Steam hydrodistillation extraction is a common extraction method and suitable for most of the plant materials. The technique is also inexpensive and holds potential for commercialization. The quality of kaffir lime peel essential oil is estimated based on GC-MS $[13,17]$. Even though previous studies have

This is an open access journal, and articles are distributed under the terms of the Attribution 4.0 International (CC BY 4.0) License. This license lets others distribute, remix, tweak, and build upon your work, even commercially, as long as they credit the author for the original creation. You must give appropriate credit, provide a link to the license, and indicate if changes were made. 
highlighted the essential oil can be obtained from kaffir lime leaves, the oil yield extracted from the peel has been shown to be higher than that from leaves [18]. The aim of this study is to determine the physico-chemical properties of the kaffir lime peel and characterization of its essential oil. The chemical composition analysis is done through gas-chromatography coupled with mass spectrometry (GC-MS).

\section{EXPERIMENTAL}

Kaffir lime samples are harvested and selected from the border area of An Giang province (coordinates 10 $22^{\circ} 52 \mathrm{~B}$ $105^{\circ} 25^{\prime} 12$ D), located in the southwest of Vietnam. Mature fruits are washed and dried at room temperature. Then, the lemon is peeled off the shell.The flesh was removed and crushed in the blender for $10 \mathrm{~s}$ to the size of approximately $0.5 \mathrm{~mm}$. In average, $1 \mathrm{~kg}$ of kaffir lime resulted in $0.5 \mathrm{~kg}$ of shell.

Extraction of essential oil of kaffir lime: By using automated steam distillation process, essential oil were extracted from fresh (within 1 day) peels ( $500 \mathrm{~g} / \mathrm{batch})$, steam running speed is slightly $12 \mathrm{~mL} / \mathrm{min}$. The total running time is $3.5 \mathrm{~h}$ (after about 15 min starting from the first liquid drop).

Physico-chemical analyses: Preliminary analysis of the quality of essential oils was performed by sensesto study the external signs such as smell, taste, colour, transparency (TCVN 8460: 2010). Some basic physical and chemical parameters of the raw materials have been identified including some criteria for finished oil products analyzed by TCVN: density of essential oils, acid index (TCVN 8450: 2010), ester index (TCVN 8451: 2010), rotator power and refractive index. The experiments were repeated three times.

GC-MS analysis of chemical composition: GC-MS is applied to investigate the composition of the essential oils of all samples. Briefly, $25 \mu \mathrm{L}$ of sample of essential oil was mixed in $1.0 \mathrm{~mL}$ of $n$-hexane. The used instrument was GC Agilent 6890N, MS 5973 inert with HP5-MS column, head column pressure 9.3 psi. GC-MS system was performed following conditions: carrier gas $\mathrm{He}$; flow rate $1.0 \mathrm{~mL} / \mathrm{min}$; split 1:100; injection volume $1.0 \mu \mathrm{L}$; injection temperature $250^{\circ} \mathrm{C}$; oven temperature progress included an initial hold at $50{ }^{\circ} \mathrm{C}$ for 2 min, then increased by $2^{\circ} \mathrm{C} / \mathrm{min}$ to $80^{\circ} \mathrm{C}$, and increased by 5 ${ }^{\circ} \mathrm{C} /$ min to $150{ }^{\circ} \mathrm{C}$, continue rising to $200^{\circ} \mathrm{C}$ at $10^{\circ} \mathrm{C} / \mathrm{min}$ and rise to $300^{\circ} \mathrm{C}$ at $20^{\circ} \mathrm{C} / \mathrm{min}$ for $5 \mathrm{~min}$.

\section{RESULTS AND DISCUSSION}

Kaffir lime essential oil yield achieved $1.8 \%$ by steam distillation. The yield of essential oil is higher than a report of Kasuan [19] where a yield of $1.34 \%$ was attained. The obtained essential oil was a clear liquid, insoluble in water and very volatile. The oil had a light yellow and light fragrance. The measured density of essential oils was 0.8587 , which is lower than 1 indicated that essential oils are lighter than water. In the sense of the indicators, the acid index would be indicative of free acids in the oil. In addition, low acid index (0.667) shows that kaffir lime oil shows fine quality in terms of odour and essential oil content of a newly extracted essential oil. The acid index depends on the extraction method, freshness and storage time of the essential oil. When being stored for a long time, acidity of the essential oil will increase due to oxidation and esterification in the degraded essential oil. On the other hand, high measured ester index (4.203) indicates abundance of ester and glycerin existing in kaffir lime oil, in which the latter primarily contributes to the aroma of many essential oils (Table-1).

TABLE-1 CHEMICAL INDEXES OF ESSENTIAL OIL OF KAFFIR LIME

Organoleptic characteristics

\begin{tabular}{lc}
\hline Aspect & Liquid \\
Colour & Clear liquid, light yellow \\
Odour & Specific \\
Density at $20^{\circ} \mathrm{C}$ & 0.8587 \\
Acid index & 0.667 \\
Ester index & 4.203 \\
Rotator power & +3 \\
Refractive index & 1.469 \\
\hline
\end{tabular}

Present study revealed that steam distillation of the samples gave different amounts of essential oil. Table-2 shows that 20 components were identified in steam distillation oil of kaffir lime, and GC chromatogram of peel essential oil is presented in Fig. 1. To obtain accurate peaks at 9.2 and 9.3, measurement and dilution were performed twice. A peak at 11.97 is a mixture of limonene and sylvestrene. The major components were $\alpha$ pinene (34.741\%), sabinene (23.637\%), D-limonene (19.08 $\%)$, citronellal $(8.181 \%)$ and $\alpha$-pinene (3.378\%). The results revealed that $\alpha$-pinene was a main active compound of Citrus hystrix peel oil. All other components represent in amount lower than $2 \%$. In GC-MS, the retention time is the time at which the compound elutes from the column. Most of the main compounds of Citrus hystrix essential oils appear after $15 \mathrm{~min}$ of steam distillation, volatiles (sabinene, $\alpha$-pinene, limonene and $\alpha$-pinene) have resulted in a high maximum area ratio. In addition, the extraction time longer than $15 \mathrm{~min}$ does not raise the maximum area ratio of most volatiles. As can be seen from Table-2, the major compounds found from the oil samples are

TABLE-2

\begin{tabular}{|c|c|c|c|}
\hline \multicolumn{4}{|c|}{$\begin{array}{c}\text { TABLE-2 } \\
\text { CHEMICAL COMPOSITION, RETENTION INDICES } \\
\text { AND PERCENTAGE COMPOSITION OFKAFFIR } \\
\text { LIME ESSENTIAL OILKAFFIR LIME }\end{array}$} \\
\hline Peak & Compound & R.T & This study $\%$ \\
\hline 1 & Origanene & 7.167 & 0.264 \\
\hline 2 & $\alpha$-Pinene & 7.397 & 3.378 \\
\hline 3 & Camphene & 7.983 & 0.222 \\
\hline 4 & Sabinene & 9.196 & 23.637 \\
\hline 5 & $\beta$-Pinene & 9.3 & 34.741 \\
\hline 6 & $\beta$-Myrcene & 10.095 & 1.04 \\
\hline 7 & Terpilene & 11.298 & 0.66 \\
\hline 8 & D-Limonene & 11.967 & 19.08 \\
\hline 9 & Moslene & 13.692 & 1.081 \\
\hline 10 & Linalool oxide & 14.529 & 0.907 \\
\hline 11 & Terpinolene & 15.449 & 0.158 \\
\hline 12 & Linalyl oxide & 15.501 & 0.581 \\
\hline 13 & Linalol & 16.338 & 0.603 \\
\hline 14 & Citronellal & 19.391 & 8.181 \\
\hline 15 & L-4-terpineol & 20.395 & 3.178 \\
\hline 16 & $\alpha$-Terpineol & 21.075 & 1.205 \\
\hline 17 & Copaene & 27.83 & 0.39 \\
\hline 18 & $\beta$-Cubebene & 28.29 & 0.232 \\
\hline 19 & Caryophyllene & 29.158 & 0.244 \\
\hline 20 & Cadinene & 32.023 & 0.218 \\
\hline
\end{tabular}




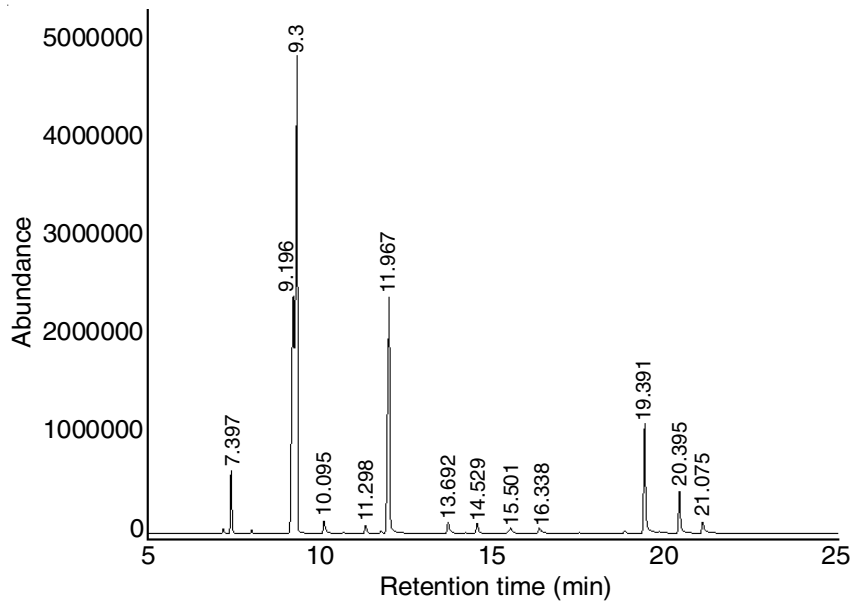

Fig. 1. Result of chromatography of Kaffir lime peels essential oil

$\alpha$-pinene, sabinene and limonene, which are higher than previously reported results [20-22]. Furthermore, the previous studies showed thatconsiderable differences were observed in kaffir lime essential oil composition: L-citronellal (12.56\%), L-limonene (11.78 \%), sabinene (20.13\%), linalool (1.82\%), $\beta$-citronellol (3.34 \%), citronellyl (1.67\%) [18]. However, $\alpha$ pinene, which gives a woody-green odour to the oil sample, contributes to the highest concentration in extracted oil samples gives a woody-green odour to the oil sample. The other essential compounds are limonene and sabinene which help increase spiciness taste and distinctively strong aroma, respectively. Kaffir lime oil was composed of oxygenated monoterpene and hydrocarbon monoterpene components that have similar boiling points.

Fig. 2 compared different compositions of kaffir lime peel oil in different countries [23]. There are four main compounds in kaffir lime peel oil including limonene, sabinene, $\alpha$-pinene, and citronellal. Fig. 3 illustrates the MS spectrum of volatiles compounds from kaffir lime peels oil including abinene, $\beta$-pinene, limonene and citronella.These differences are mainly due to monoterpene bicyclic hydrocarbons such as sabinene,

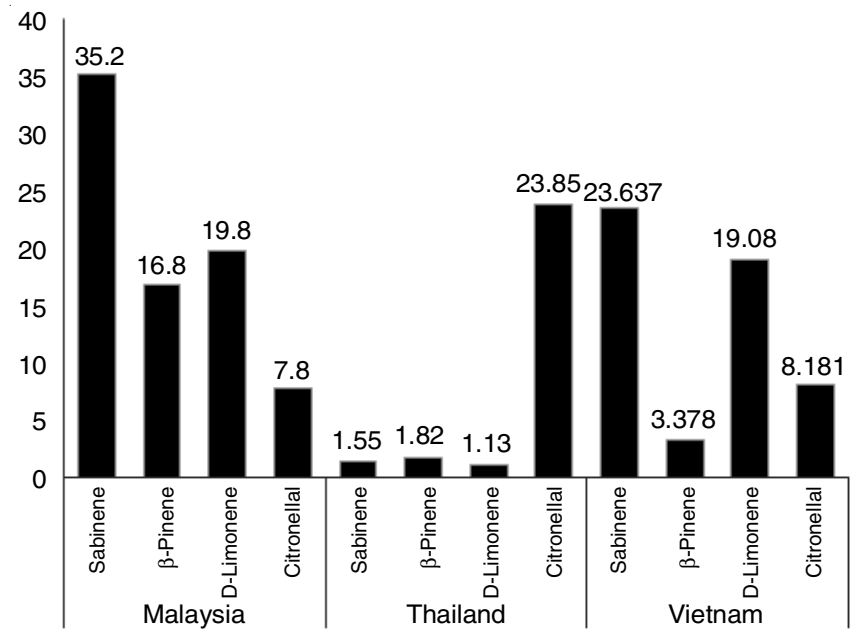

Fig. 2. Comparison of main compounds obtained from Kaffir lime peel oil grown in different countries

$\beta$-pinene and $\alpha$-pinene in the heated aqueous medium, which are susceptible to isomerization and hydration reactions and therefore tend to disappear in distilled oils.

\section{Conclusion}

Kaffir lime (Citrus hystrix DC) essential oil was studied in this research for its physico-chemical characteristics and composition. The essential oil yields achieved $1.8 \%$. Physicochemical parameters included average specific gravity $(0.8587$ $\left.\mathrm{g} / \mathrm{cm}^{3}\right)$, ester index $(4.203 \mathrm{mg} \mathrm{KOH} / \mathrm{g})$, acid index $(0.667 \mathrm{mg}$ $\mathrm{KOH} / \mathrm{g}$ ), refractive index (1.469) and rotator power of +3 . Moreover, this research has identified the volatile, aromtic compounds and key odorants of fresh and dried kaffir lime leaves identified by GC-MS. Essential oils contain 20 main ingredients in which major constituents are $\beta$-pinene (34.741\%), sabinene (23.637 $\%)$, D-limonene (19.08\%), citronellal (8.181\%) and $\alpha$-pinene (3.378\%). The results obtained showed Citrus hystrix peel contains more amount of $\beta$-pinene per unit volume of essential oil. The results showed the different chemical components as well as the physico-chemical properties of essential oils
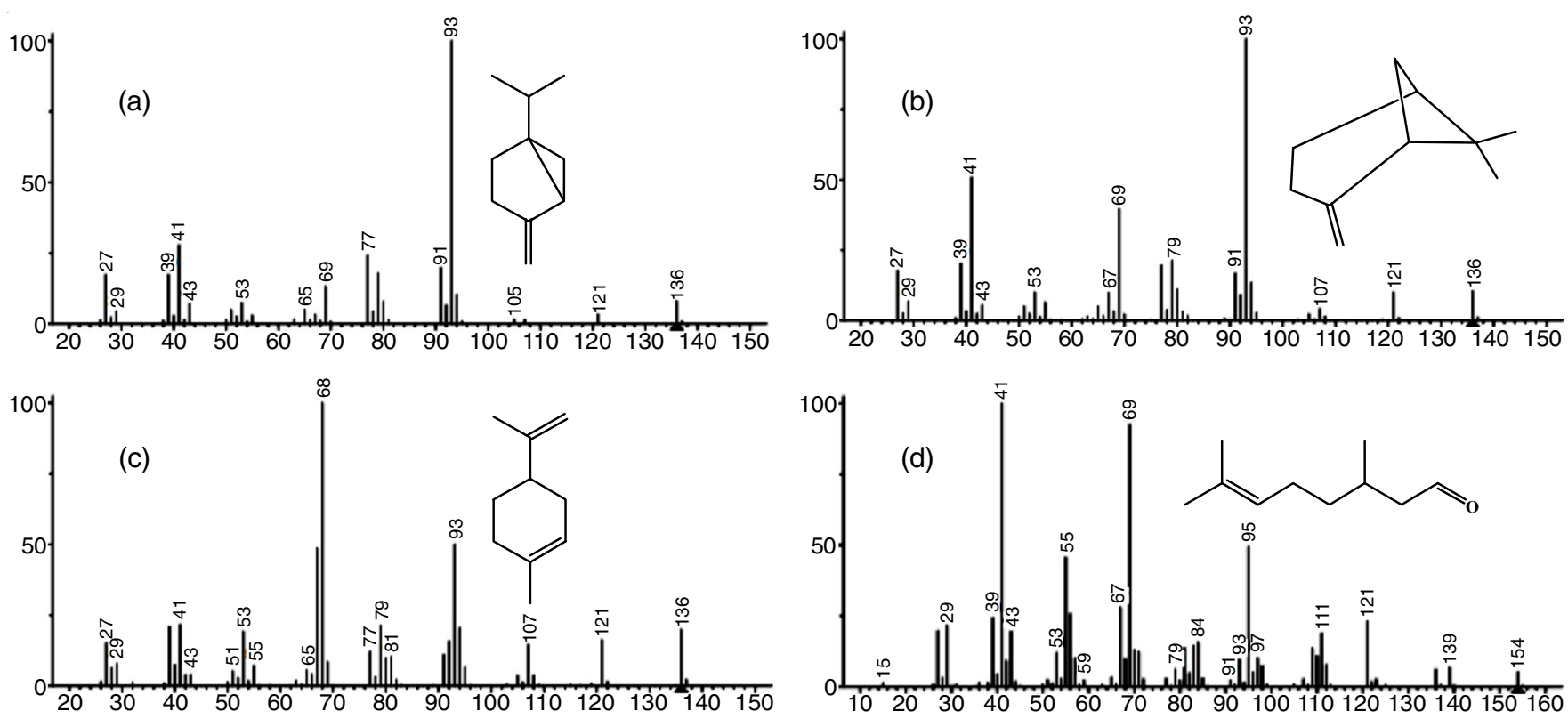

Fig. 3. MS spectra of volatiles compounds from Kaffir lime peels oil, sabinene (a), $\beta$-pinene (b), limonene (c), citronellal (d) 
affected by environmental conditions, extraction methods, and harvesting season. In conclusion, this study confirmed the important role of essential oil of Citrus hystrix in cosmetic application.

\section{ACKNOWLEDGEMENTS}

This research is funded by Nguyen Tat Thanh University, Ho Chi Minh City, Vietnam.

\section{CONFLICT OF INTEREST}

The authors declare that there is no conflict of interests regarding the publication of this article.

\section{REFERENCES}

1. V.K. Bajpai and K.-H. Baek, J. Essen. Oil Bearing Plants, 19, 1 (2016); https://doi.org/10.14233/ajchem.2018.21032.

2. S. Burt, Int. J. Food Microbiol., 94, 223 (2004); https://doi.org/10.1016/j.ijfoodmicro.2004.03.022.

3. F. Bakkali, S. Averbeck, D. Averbeck and M. Idaomar, Food Chem. Toxicol., 46, 446 (2008); https://doi.org/10.1016/j.fct.2007.09.106.

4. J.F. Ayala-Zavala, G. A. Gonzalez-Aguilar and L. Del Toro-Sànchez, J. Food Sci., 74, 84 (2009); https://doi.org/10.1111/j.1750-3841.2009.01294.x.

5. J. Gutierrez, C. Barry-Ryan and P. Bourke, Food Chem. Toxicol., 46, 446 (2008); https://doi.org/10.1016/j.fct.2007.09.106.

6. B. Ali, N. A. Al-Wabel, S. Shams, A. Ahamad, S. A. Khan and F. Anwar, Asian Pac. J. Trop. Biomed., 5, 601 (2015); https://doi.org/10.1016/j.apjtb.2015.05.007.

7. T.H. Tran, L.K. Ha, D.C. Nguyen, T.P. Dao, L.T.H. Nhan, D.H. Nguyen, T.D. Nguyen, D.-V.N. Vo, Q.T. Tran and L.G. Bach, Processes, 7, 56 (2019); https://doi.org/10.3390/pr7020056.

8. T. Tran, H. Nguyen, D. Nguyen, T. Nguyen, H. Tan, L. Nhan, D. Nguyen, L. Tran, S. Do and T. Nguyen, Processes, 6, 206 (2018); https://doi.org/10.3390/pr6110206.
9. H. Zhai, H. Liu, S. Wang, J. Wu and A.-M. Kluenter, Anim. Nutr., 4, 179 (2018); https://doi.org/10.1016/j.aninu.2018.01.005.

10. M. Perricone, E. Arace, M.R. Corbo, M. Sinigaglia and A. Bevilacqua, Front. Microbiol., 6, 76 (2015); https://doi.org/10.3389/fmicb.2015.00076.

11. R. Budiarto, R. Poerwanto, E. Santosa, D. Efendi and A. Agusta, $J$. Trop. Crop Sci., 6, 138 (2019).

12. V. Srisukh, C. Tribuddharat, V. Nukoolkarn, N. Bunyapraphatsara, K. Chokephaibulkit, S. Phoomniyom, S. Chuanphung and S. Srifuengfung, Sci. Asia, 38, 212 (2012); https://doi.org/10.2306/scienceasia1513-1874.2012.38.212.

13. P. Minyak, C. Hystrix, D.C.L. Purut, M. Kaedah, W. Automatik, A Komposisi, H. Minyak, N. Kasuan, Z. Muhammad, Z. Yusoff, M. Hezri, F. Rahiman, M.N. Taib and Z.A. Haiyee, Malays. J. Anal. Sci., 17, 359 (2013).

14. A. Rattanamaneerusmee, K. Thirapanmethee, Y. Nakamura and M.T. Chomnawang, Pharm. Sci. Asia, 45, 154 (2018); https://doi.org/10.29090/psa.2018.03.154.

15. F. Agouillal, Z.M. Taher, H. Moghrani, N. Nasrallah and H. El Enshasy, Biosci. Biotechnol. Res. Asia, 14, 285 (2017); https://doi.org/10.13005/bbra/2446.

16. J. Waikedre, A. Dugay, I. Barrachina, C. Herrenknecht, P. Cabalion and A. Fournet, Chem. Biodivers., 7, 871 (2010); https://doi.org/10.1002/cbdv.200900196.

17. Z.A. Haiyee and C. Winitkitcharoen, Int. J. Food, Nutr. Public Health, 5, 201 (2012)

18. O.M. Nor, J. Trop. Agric. Food Sci., 27, 225 (1999).

19. N. Kasuan, M. Yunus, M.H.F. Rahiman, S.R.S. Aris and M.N. Taib, IEEE Student Conf. Res. Dev., 479 (2009).

20. I.M. Helander, H.-L. Alakomi, K. Latva-Kala, T. Mattila-Sandholm, I. Pol, E.J. Smid, L.G.M. Gorris and A. von Wright, J. Agric. Food Chem., 46, 3590 (1998); https://doi.org/10.1021/jf980154m.

21. A. Sato, K. Asano and T. Sato, J. Essent. Oil Res., 2, 179 (1990); https://doi.org/10.1080/10412905.1990.9697857.

22. S.K. Filoche, K. Soma and C.H. Sissons, Oral Microbiol. Immunol., 20, 221 (2005); https://doi.org/10.1111/j.1399-302X.2005.00216.X.

23. F. Agouillal, Z. M. Taher, H. Moghrani, N. Nasrallah and H. El Enshasy, Biosci. Biotechnol. Res. Asia, 14, 285 (2017); https://doi.org/10.13005/bbra/2446. 